\title{
Dokumentasi Software Testing Berstandar IEEE 829-2008 untuk Learning Management System Fakultas Ilmu Komputer Universitas Subang
}

\author{
Tazkia Salsabila Ardan ${ }^{1}$, Denada Fatimah Zahra², Fikri Rahmat Junaedi ${ }^{3}$, Septian Rheno \\ Widianto $^{4}$ \\ Jurusan Sistem Informasi Bisnis, \\ Sekolah Tinggi Manajemen Ilmu Komputer LIKMI \\ Jl. Ir. H. Juanda No.96, Lebakgede, Kecamatan Coblong, Kota Bandung, Indonesia \\ denada.zahr@gmail.com ${ }^{1}$,info@likmi.id ${ }^{2,3}$, septian.rheno@yahoo.de ${ }^{4}$
}

Diterima: 16 November 2020. Disetujui: 5 Januari 2021. Dipublikasikan: 6 Januari 2020.

\begin{abstract}
Learning Management System (LMS) is a new software application that is used to help plan, and implement a learning process at the Faculty of Computer Science, University of Subang. Concerns about the quality of the system that cannot be controlled properly due to the absence of standard documentation on the LMS of the Faculty of Computer Science. And according to DcLone and McLean, the higher the quality of information produced by an information system will further increase user satisfaction, in this case the Faculty of Computer Science as a division of the University of Subang with the service sector, the quality of information is very influential in increasing the satisfaction of students and lecturers at the Faculty. Computer science. Therefore, standardized documentation is needed so that the quality of the LMS system at the Faculty of Computer Science, University of Subang can be maintained and developed properly. System testing is carried out using the Software Testing Learning Center (STLC) methodology which is divided into six testing phases, namely Requirement Analysis, Test Planning, Test Case Development, Text Execution and Closure. The test was conducted with 16 types of tests from 4 aspects, namely aspects of security, data integrity, functional, and recovery. The test results show that the security aspect produces $100 \%$ pass from 8 testing stages with 3 different cases. In the aspect of data integrity, it also produces $100 \%$ passes from 20 testing stages with 2 different cases. While the functional aspect only produced 82\% Passes 15 times from 18 testing stages with 7 different cases. Another aspect is the recovery aspect which results in 100\% pass from the testing phase with 2 different cases. After carrying out the testing process for the LMS system, the Faculty of Computer Science is a fairly good standard.
\end{abstract}

Keywords: Learning Management System (LMS, testing documentation, Software Testing Life Cycle (STLC)

Abstrak-- Learning Management System (LMS) merupakan sebuah aplikasi software baru yang digunakan untuk membantu merencanakan, dan mengimplementasikan sebuah proses pembelajaran Fakultas Ilmu Komputer, Universitas Subang. Kekhawatiran terhadap kualitas sistem yang tidak dapat dikontrol dengan baik dikarenakan belum adanya pendokumentasian yang berstandar pada LMS Fakultas Ilmu Komputer. Serta menurut DcLone and McLean semkain tinggi kualitas informasi yang dihasilkan suatu sistem informasi, akan semakin meningkatkan kepuasan pengguna, dalam hal ini Fakultas IImu Komputer sebagai divisi bagian dari Universitas Subang dengan bidang pelayanan, kulitas informasi sangat berpengaruh kepada meningkatnya kepuasan para mahasiswa dan dosen di Fakultas Ilmu Komputer. Maka dari itu diperlukannya dokumentasi yang berstrandar agar kualitas sistem LMS Fakultas Ilmu Komputer, Universitas Subang dapat terjaga dan berkembang dengan baik. Pengujian sistem dilakukan dengan menggunakan metodologi Software Testing Learning Center (STLC) yang terbagi kedalam enam fase pengujian yaitu Analisis Requirement, Test Planning, Test Case Development, Text Execution dan Closure. Test dilakukan dengan 16 jenis test dari 4 aspek yaitu aspek security, data integrity, fungsional, dan recovery. Hasil pengujian memperlihatkan pada aspek security menghasilkan $100 \%$ pass dari 8 kali tahap pengujian dengan 3 case yang berbeda. Pada aspek data integrity juga menghasilkan $100 \%$ pass dari 20 kali tahap pengujian dengan 2 case yang berbeda. Sementara aspek fungsional hanya mengasilkan 82\% Pass sebanyak 15 kali dari 18 tahap pengujian dengan 7 case yang berbeda. Aspek lainnya yaitu aspek recovery menghasilkan $100 \%$ pass dari tahap pengujian dengan 2 case yang berbeda. Setelah melakukan proses pengujian terhadap sistem LMS Fakultas Ilmu Komputer adalah standar yang sudah cukup baik.

Kata kunci: Learning Management System (LMS, dokumentasi testing, Software Testing Life Cycle (STLC)

\section{PENDAHULUAN}

Pengujian program komputer (software testing) adalah merupakan suatu investigasi yang dilakukan untuk mendapatkan informasi mengenai kualitas dari produk atau layanan yang sedang diuji. Pengujian seperti ini akan dapat mengukur kualitas program secara garis besar dari segi ketepatan (correctness), 
kelengkapan (completeness), kebergunaan (usability), kinerja (performance) dan juga segi fungsional ataupun non-fungsional lainya. Definisi testing sendiri adalah proses menganalisa suatu entitas software untuk mendeteksi perbedaan antara kondisi yang ada dengan kondisi yang diinginkan (defect/errors/bugs) dan mengevaluasi fitur-fitur dari entitas software (standar ANSI/IEEE 1059). Dengan menggunakan tahapan testing maka kualitas sistem yang digunakan akan dapat terjaga dan terdokumentasi, karena testing berperan penting untuk mengukur seberapa baik kualitas aplikasi dan pengguna dapat menggunakan aplikasinya serta menghindari hal-hal yang tidak diinginkan dalam proses pengoperasiannya.

Fakultas Ilmu Komputer Universitas Subang merupakan salah satu fakultas yang menggunakan Learning Management System. Learning Management System (LMS) Fakultas Ilmu Komputer adalah sebuah aplikasi software yang dapat membantu yang dapat membantu merencanakan, mengimplementasikan sebuah proses pembelajaran. LMS memungkinkan pemilik atau pembuat coruse untuk memanage, menyampaikan, dan memonitor para muridnya. LMS memadukan antara kursus tradisional dengan media digital dan alat interaktif meliputi kursus online, virtual live sessions dan forum diskusi.

Hingga saat ini LMS Fakultas Ilmu Komputer masih belum memiliki dokumentasi testing dikarenakan, ini LMS Fakultas Ilmu Komputer sendiri merupakan sistem manajemen pembelajaran baru dan memenuhi kebutuhan pengguna saat ini. Sebagai salah satu aset penting yang dimiliki fakultas, tentunya diperlukan dokumentasi yang terstandar agar kualitas sistem informasi yang dimiliki fakultas dapat terjaga dan berkembang dengan baik. Kekhawatiran terhadap kualitas sistem yang tidak dapat dikontrol dengan baik dikarenakan belum adanya pendokumentasian yang berstandar pada LMS Fakultas Ilmu Komputer. Serta menurut DcLone and McLean semkain tinggi kualitas informasi yang dihasilkan suatu sistem informasi, akan semakin meningkatkan kepuasan pengguna, dalam hal ini Fakultas Ilmu Komputer sebagai divisi bagian dari Universitas Subang dengan bidang pelayanan, kulitas informasi sangat berpengaruh kepada meningkatnya kepuasan para Mahasiswa dan Dosen di Fakultas Ilmu Komputer. Standar yang akan digunakan dalam pengujian perangkat lunak kali ini adalah IEEE 8292008 Software Testing yang merupakan sebuah standar yang digunakan dalam proses menganalisis sebuah perangkat lunak untuk mendeteksi perbedaan kondisi yang ada dengan kondisi yang diperlukan atau yang sering disebut bug dan untuk mengevaluasi fitur dari perangkat lunak [1]. Pengerjaan dokumen testing ini menggunakan metode Software Testing Life Cycle (STLC) yang didefinisikan sebagai serangkaian kegiatan yang dilakukan untuk melakukan pengujian perangkat lunak yang mengacu pada proses pengujian dengan langkah-langkah spesifik yang harus dilakukan dalam urutan tertentu untuk memastikan bahwa sasaran mutu terpenuhi [2], metode ini dibagi menjadi 6 fase, yaitu analisis, planning, test case, setup, dan closure.

Penelitian terdahulu mengenai software testing oleh Adi Purnomo (2013) dengan judul "Software Testing Aplikasi Website PT. Gramedia Menggunakan Metode Blackbox Pada PT WGS Bandung" [3]. Peneliti mendapatkan klien dari PT. Gramedia Pustaka Utama dengan mengetes aplikasi berbasis website berdasarkan Functional Test, Security Test, Front End Performance Test, Back End Performance Test dan User Interface Test pada web staging perusahaan yaitu www.publishing.gramediana.com. Penelitian lain tentang software Testing oleh Reza Maulana, Indrawan Liwanto, Christouvel Lucma (2017) dengan judul "Software Testing pada Aplikasi Website PT Semen Tonasa menggunakan Metode Assessment Vulnerability" [4]. Peneliti menguji coba aplikasi berbasis website yang dimiliki PT Semen Tonasa berdasarkan Security Test pada Web perusahaan yaitu sementonasa.co.id dengan menggunakan Teknik String Based Sql Injection untuk mencari tahu kelemahan alamat web tesebut. Penelitian selanjutnya yaitu yang berkaitan dengan software testing berstandar IEEE 829-2008 pernah di lakukan sebelumnya oleh Muchamad Adam Harris Anwar dan Yudhi Kurniawan (2019) dengan judul "Dokumen Software Testing Berstandar IEEE 829-2008 Untuk Sistem Informasi Terintegrasi Universitas" [5]. Penelitian ini dilakukan karena Ma Chung Integrate Information System belum mempunyai pendokumentasian yang terstandar pada yang menyebabkan kualitas sistem tidak dikontrol dengan baik, dengan menggunakan metode SDLC (Software Testing Life Cycle). Dari beberapa penelitian yang telah diuraikan, maka terdapat perbedaan dengan penelitian ini seperti sofware yang dilakukan testing sangat berbeda, serta tempat penelitian yang berbeda pula.

\section{METODE PENELITIAN}

Dokumentasi pengujian perangkat lunak adalah elemen penting yang meningkatkan aktivitas eksperimental ke tingkat pengujian perangkat lunak. Dokumentasi merupakan sebuah artefak yang tujuannya untuk menyampaikan informasi tentang 
sistem perangkat lunak yang menyertainya. Selain itu dokumentasi mempunyai fungsi sebagai berikut:

1. Bertindak sebagai media komunikasi antar anggota pengembang tim,

2. Penyimpanan sistem informasi untuk digunakan oleh maintenance engineers,

3. Membantu manajer proyek dalam merencanakan, mengatur anggaran, dan penjadwalan dalam proses pembangunan perangkat lunak,

4. Memberi penjelasan kepada pengguna bagaimana cara menggunakan dan mengelola sistem yang dibangun.

Sebagai tempat penyimpanan informasi, dokumen semestinya harus berisi informasi yang lengkap, valid, mudah dimengerti, dan up-to-date. Tetapi banyak pengembang yang membiarkan dokomen yang dibuat tidak memberikan informasi yang lengkap atau informasi yang tidak diperbaharui (out-of-date).

R Shujjar mengklasifikasikan dokumentasi ke dalam empat bagian yaitu dokumen kebutuhan, arsitektur dan desain, dokumen teknis, dokumen end user, dan dokumen pemasaran. Dokumen kebutuhan merupakan dokumen yang menjelaskan tentang atribut, kemampuan, karakterisitik, atau kualitas dari suatu sistem yang merupakan dasar dari pembuatan suatu perangkat lunak. Dokumen arsitektur dan desain yaitu dokumen yang menjelaskan tentang arsitektur sistem dan prinsip-prinsip konstruksi yang akan digunakan dalam desain komponen perangkat lunak. Dokumen teknis merupakan dokumentasi dari kode, algoritma dan interface. Dokumen end user merupakan dokumen manual tentang bagaimana perangkat lunak tersebut digunakan. Dokumen pemasaran berisi bagaimana cara pemasaran dari produk dan analisis permintaan pasar.

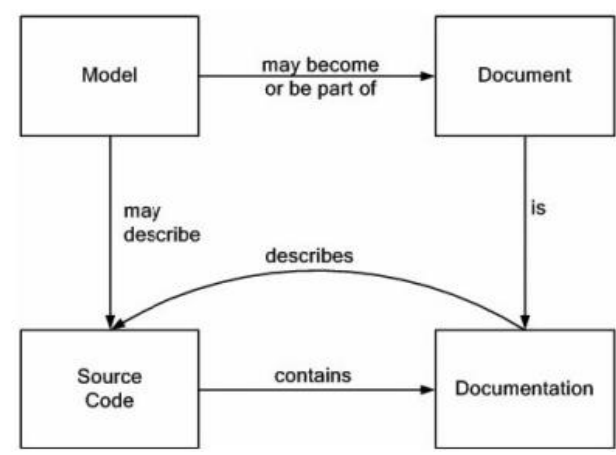

Gambar 1. Hubungan antara Source Code, Model, Document, dan Documentation
Standar Pengujian perangkat lunak memiliki kelebihan dan kekurangan masing-masing. Ringkasan perbedaan masing-masing standar dapat di lihat pada Tabel 1.

TABEL I. PERBANDINGAN STANDAR PENGUJIAN PERANGKAT LUNAK

\begin{tabular}{|c|c|c|c|}
\hline \multirow{2}{*}{$\begin{array}{l}\text { Aspek } \\
\text { Pembandi- } \\
\text { ng }\end{array}$} & \multicolumn{3}{|c|}{ Nama Standard } \\
\hline & IEEE-829 & IEEE 1008 & BS-7925 \\
\hline Deskripsi & $\begin{array}{l}\text { Merupakan } \\
\text { Standar yang } \\
\text { mendefinisika } \\
\text { n sekumpulan } \\
\text { dokumen } \\
\text { untuk } \\
\text { perangkat } \\
\text { lunak dan } \\
\text { pengujian } \\
\text { sistem }\end{array}$ & $\begin{array}{l}\text { Merupakan } \\
\text { standar yang } \\
\text { medefinisika } \\
\mathrm{n} \\
\text { pendekatan } \\
\text { pengujian } \\
\text { unit yang } \\
\text { menjadi } \\
\text { acuan } \\
\text { praktik } \\
\text { pengujian } \\
\text { perangkat } \\
\text { lunak }\end{array}$ & $\begin{array}{l}\text { Merupakan } \\
\text { Standar yang } \\
\text { mendefinisika } \\
\mathrm{n} \text { proses } \\
\text { pengujian } \\
\text { menggunakan } \\
\text { pendekatan } \\
\text { component } \\
\text { testing }\end{array}$ \\
\hline $\begin{array}{l}\text { Proses } \\
\text { Pengujian }\end{array}$ & $\begin{array}{l}\text { Proses } \\
\text { pengujian } \\
\text { disesuikan } \\
\text { oleh penguji }\end{array}$ & $\begin{array}{l}\text { Definisi } \\
\text { serangkaian } \\
\text { aktivitas } \\
\text { pengujian } \\
\text { unit }\end{array}$ & $\begin{array}{l}\text { Definisi } \\
\text { serangkaian } \\
\text { proses } \\
\text { pengujian } \\
\text { komponen }\end{array}$ \\
\hline $\begin{array}{l}\text { Dokumenta } \\
\text { si Pengujian }\end{array}$ & $\begin{array}{l}\text { Mendefinisika } \\
\mathrm{n} \text { format } \\
\text { dokumentasi } \\
\text { untuk } \\
\text { tahapan } \\
\text { pengujian, } \\
\text { yang kepada } \\
\text { penguji } \\
\text { diberikan } \\
\text { kebebasan } \\
\text { untuk mengisi } \\
\text { semua atau } \\
\text { tidak. }\end{array}$ & $\begin{array}{l}\text { Tidak } \\
\text { menjelaskan } \\
\text { mengenai } \\
\text { dokumentasi } \\
\text { atau output } \\
\text { yang } \\
\text { berhubungan } \\
\text { dengan } \\
\text { pengajuan } \\
\text { unit }\end{array}$ & $\begin{array}{l}\text { Tidak } \\
\text { menjelaskan } \\
\text { dokumen } \\
\text { output standar }\end{array}$ \\
\hline
\end{tabular}

Organisasi internasional seperti IEEE dan ISO telah menerbitkan standar untuk dokumentasi pengujian perangkat lunak. IEEE 829-2008, juga dikenal sebagai 829 Standard for Software and System Test Documentation, adalah standar IEEE yang menetapkan bentuk sekumpulan dokumen untuk digunakan dalam delapan tahap pengujian perangkat lunak dan pengujian sistem, setiap tahap berpotensi menghasilkan sendiri jenis dokumen terpisah. Standar tersebut menetapkan format dokumen-dokumen ini, tetapi tidak menetapkan apakah semuanya harus diproduksi, juga tidak memasukkan kriteria apa pun mengenai konten yang memadai untuk dokumendokumen ini. Ini adalah masalah penilaian di luar lingkup standar. Dokumen tersebut adalah:

1. Master Test Plan (MTP): Tujuan Master Test Plan (MTP) adalah untuk menyediakan 
perencanaan pengujian dan dokumen manajemen pengujian secara keseluruhan untuk berbagai level pengujian (baik dalam satu proyek atau di beberapa proyek).

2. Rencana Uji Tingkat (LTP): Untuk setiap LTP, ruang lingkup, pendekatan, sumber daya, dan jadwal kegiatan pengujian untuk tingkat pengujian yang ditentukan perlu dijelaskan. Item yang diuji, fitur yang akan diuji, tugas pengujian yang akan dilakukan, personel yang bertanggung jawab untuk setiap tugas, dan risiko terkait perlu diidentifikasi.

3. Level Test Design (LTD): Merinci kasus tes dan hasil yang diharapkan serta kriteria lulus tes.

4. Kasus Uji Tingkat (LTC): Menentukan data uji untuk digunakan dalam menjalankan kasus uji yang diidentifikasi dalam Desain Uji Tingkat.

5. Prosedur Uji Tingkat (LTPr): Merinci cara menjalankan setiap pengujian, termasuk prasyarat penyiapan dan langkah-langkah yang perlu diikuti.

6. Level Test Log (LTL): Untuk memberikan catatan kronologis detail yang relevan tentang pelaksanaan pengujian, misalnya merekam kasus pengujian mana yang dijalankan, siapa yang menjalankannya, dalam urutan apa, dan apakah setiap pengujian berhasil atau gagal.

7. Anomaly Report (AR): Untuk mendokumentasikan setiap peristiwa yang terjadi selama proses pengujian yang memerlukan investigasi. Ini mungkin disebut masalah, insiden pengujian, cacat, masalah, masalah, anomali, atau laporan kesalahan. Dokumen ini sengaja diberi nama sebagai laporan anomali, dan bukan laporan kesalahan. Alasannya adalah bahwa ketidaksesuaian antara hasil yang diharapkan dan yang sebenarnya dapat terjadi karena sejumlah alasan selain kesalahan dalam sistem. Ini termasuk hasil yang diharapkan salah, pengujian yang dijalankan tidak benar, atau ketidakkonsistenan dalam persyaratan yang berarti bahwa lebih dari satu interpretasi dapat dibuat. Laporan tersebut terdiri dari semua rincian insiden seperti hasil aktual dan yang diharapkan, ketika gagal, dan bukti pendukung yang akan membantu dalam penyelesaiannya. Laporan tersebut juga akan mencakup, jika memungkinkan, penilaian dampak suatu insiden pada pengujian.

8. Laporan Status Tes Sementara Tingkat (LITSR): Untuk meringkas hasil sementara dari kegiatan pengujian yang ditunjuk dan secara opsional untuk memberikan evaluasi dan rekomendasi berdasarkan hasil untuk tingkat tes tertentu.
9. Laporan Uji Tingkat (LTR): Meringkas hasil dari kegiatan pengujian yang ditunjuk dan untuk memberikan evaluasi dan rekomendasi berdasarkan hasil setelah pelaksanaan pengujian selesai untuk tingkat pengujian tertentu.

10. Laporan Uji Induk (MTR): Untuk meringkas hasil dari tingkat kegiatan pengujian yang ditunjuk dan untuk memberikan evaluasi berdasarkan hasil ini. Laporan ini dapat digunakan oleh organisasi mana pun yang menggunakan MTP. Laporan manajemen yang memberikan informasi penting yang ditemukan oleh pengujian yang dilakukan, dan termasuk penilaian kualitas upaya pengujian, kualitas sistem perangkat lunak yang diuji, dan statistik yang diperoleh dari Anomaly Reports. Laporan tersebut juga mencatat pengujian apa yang telah dilakukan dan berapa lama waktu yang dibutuhkan untuk meningkatkan perencanaan pengujian di masa mendatang. Dokumen akhir ini digunakan untuk menunjukkan apakah sistem perangkat lunak yang diuji sesuai untuk tujuan menurut memenuhi kriteria penerimaan yang ditentukan oleh pemangku kepentingan proyek atau tidak.

Standar tersebut merupakan bagian dari silabus pelatihan Yayasan ISEB dan Sertifikat Praktisi dalam Pengujian Perangkat Lunak yang dipromosikan oleh British Computer Computer Society. ISTQB, mengikuti pembentukan silabusnya sendiri berdasarkan silabus ISEB dan ASQF Jerman, juga mengadopsi IEEE 829 sebagai standar referensi untuk perangkat lunak dan dokumentasi pengujian system. David Gelperin dan Dr. William C. Hetzel mengembangkan metodologi Systematic Test and Evaluation Process (STEP) untuk menerapkan Standar IEEE-829 yang asli untuk Dokumentasi Pengujian Perangkat Lunak. Pada penelitian ini, penulis hanya menggunakan dokumen Level Test Design (LTD).

Dokumen Testing IEEE 829 telah mengalami beberapa kali perubahan versi yang dapat dilihat di Gambar 2.

\section{A. Software Testing Life Cycle (STLC)}

Metode pengujian pada software pada studi kasus Learning System Management, Fakultas Ilmu Komputer, Universitas Subangini akan menggunakan metodologi STLC (Software Testing Life Cycle) yang membagi proses pengujian sistem menjadi enam bagian mulai dari fase analisis, perencanaan, desain, spesifikasi kebutuhan perangkat, eksekusi, hingga 
ditutup dengan hasil luaran berupa dokumentasi pengujian perangkat lunak yang secara garis besar tergambar pada penyajian Tabel 2. [8]. Penelitian ini menggunakan metode STLC didasari oleh tahapan yang terstruktur yang dimiliki metode tersebut dapat menjelaskan berbagai kegiatan secara spesifik sehingga peneliti mendapatkan kebutuhan spesifik dan terperinci untuk proses pengujian Learning Management System seperti pada Gambar 3. Pengujian perangkat lunak adalah area yang sangat luas, yang melibatkan banyak area teknis dan non-teknis lainnya, seperti spesifikasi, desain dan implementasi, pemeliharaan, proses, dan masalah manajemen dalam rekayasa perangkat lunak [6].

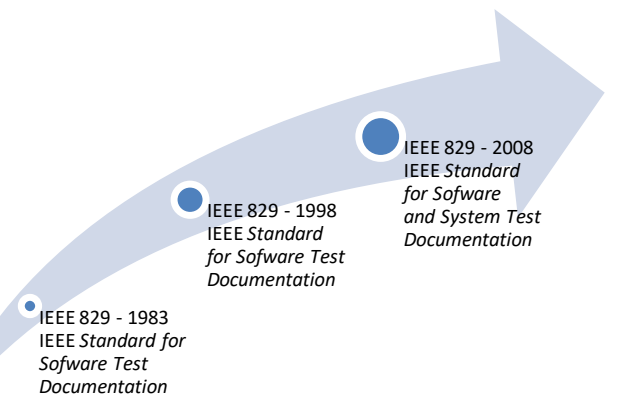

Gambar 2. Sejarah Versi Dokumen Testing IEEE 829

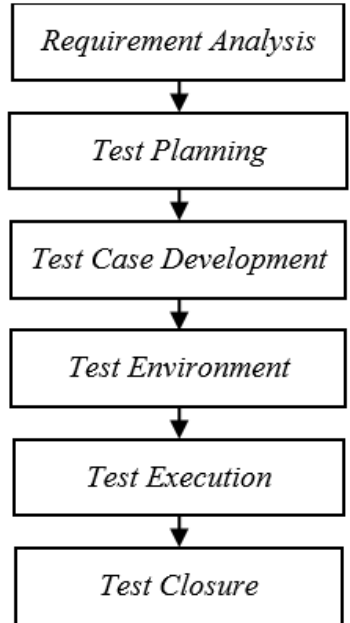

Gambar 3 Tahapan STLC

TABEL II. SOFTWARE TESTING LIFE CYCLE

\begin{tabular}{cll} 
Fase & \multicolumn{1}{c}{ Kegiatan } & \multicolumn{1}{c}{ Output } \\
\hline Analisis & Wawancara & Hasil wawancara \\
Requirement & Analisis Kebutuhan & Dokumen \\
& Sistem & Requirement \\
& Memetakan & Matrix RTM \\
& Rewuirement & \\
& menggunakan case & \\
\hline
\end{tabular}

\begin{tabular}{|c|c|c|}
\hline Fase & Kegiatan & Output \\
\hline Test Planning & $\begin{array}{l}\text { Persiapan rencana } \\
\text { pengujian }\end{array}$ & Rencana proses uji \\
\hline $\begin{array}{c}\text { Test Case } \\
\text { Development }\end{array}$ & $\begin{array}{l}\text { Membuat scenario } \\
\text { testing }\end{array}$ & $\begin{array}{l}\text { Dokumen Test } \\
\text { Case }\end{array}$ \\
\hline $\begin{array}{c}\text { Test Case } \\
\text { Development }\end{array}$ & $\begin{array}{l}\text { Melihat spesifikasi } \\
\text { perangkat yang } \\
\text { dibutuhkan }\end{array}$ & $\begin{array}{l}\text { Dokumentasi Test } \\
\text { Case/Skenario } \\
\text { Testing }\end{array}$ \\
\hline Text Execution & $\begin{array}{l}\text { Merancang tabel case } \\
\text { dengan dilengkapi } \\
\text { ekspektasi outcome }\end{array}$ & $\begin{array}{l}\text { Spesifikasi } \\
\text { hardware dan tools } \\
\text { pendukung }\end{array}$ \\
\hline Closure & $\begin{array}{l}\text { Meringkas hasil } \\
\text { pengujian } \\
\text { Evaluasi dan } \\
\text { dokumentasi }\end{array}$ & $\begin{array}{l}\text { Dokumentasi } \\
\text { software testing }\end{array}$ \\
\hline
\end{tabular}

\section{Analisis Kebutuhan}

Fase pertama yang merupakan fase Analisis merupakan fase dasar dari proses pengujian perangkat lunak. Fase ini mencakup analisis kebutuhan fungsional dan non-fungsional misalnya. persyaratan bisnis, dokumen spesifikasi fungsional dan dokumen spesifikasi teknis, dan lain-lain. Pengumpulan persyaratan dan harus dilakukan untuk penjelasan dengan pelanggan untuk mengidentifikasi hasil aktual dan yang diharapkan dari pengujian seperti Identifikasi persyaratan dan celah, yang pada dasarnya merupakan persyaratan non-fungsional seperti kegunaan, skalabilitas, kemampuan pengujian, pemeliharaan, kinerja, dan keamanan. Semua persyaratan yang tidak dapat diuji karena kendala sistem dan lingkungan pengujian harus dikomunikasikan kepada tim bisnis. Selama fase ini, tim penguji meninjau dan menganalisis persyaratan dan mengidentifikasi pengujian, yang akan dilakukan dan menetapkan prioritas untuk anggota tim penguji [7].

Tahap ini dilakukan dengan melakukan beberapa kegiatan guna menghasilkan dokumen kebutuhan pengguna. Tahapan dalam tahap ini diawali dengan kegiatan pengumpulan data melalui wawancara dengan beberapa narasumber di Fakultas Ilmu Komputer Universitas Subang mengenai software Learning Management System. Tahap kedua menganalisis hasil wawancara dan menghasilkan kesimpulan tentang kebutuhan pengguna dari beberapa aspek yang dapat diuraikan dalam Requirement Traceability Matrix yang tercantum pada Tabel 3 . Tabel tersebut digunakan untuk menentukan persyaratan pengujian dan memverifikasi persyaratan yang ada di IEEE 829-2008 terpenuhi. Melalui hasil tersebut dapat terlihat pemetaan setiap fase dalam pengujian software. 
TABEL III. REQUIREMENT TRACEABILITY MATRIX

\begin{tabular}{|c|c|c|c|c|c|c|c|c|c|}
\hline \multirow{2}{*}{\multicolumn{2}{|c|}{$\begin{array}{l}\text { Requirement } \\
\text { Traceability }\end{array}$}} & \multicolumn{8}{|c|}{ Business Requirement } \\
\hline & & BR1 & BR2 & BR3 & BR4 & BR5 & BR6 & BR7 & BR8 \\
\hline \multirow{15}{*}{$\begin{array}{l}\text { TEST } \\
\text { CASE }\end{array}$} & $\mathrm{TCl}$ & & & & & & & & \\
\hline & TC2 & & & & & & & & \\
\hline & TC3 & & & & & & & & \\
\hline & TC4 & & & & & & & & \\
\hline & TC5 & & & & & & & & \\
\hline & TC6 & & & & & & & & \\
\hline & TC7 & & & & & & & & \\
\hline & TC8 & & & & & & & & \\
\hline & TC9 & & & & & & & & \\
\hline & TC10 & & & & & & & & \\
\hline & TC11 & & & & & & & & \\
\hline & TC12 & & & & & & & & \\
\hline & TC13 & & & & & & & & \\
\hline & TCl4 & & & & & & & & \\
\hline & TC15 & & & & & & & & \\
\hline
\end{tabular}

\section{Test Planning}

Tahap persiapan ujian meliputi penyusunan rencana ujian, kasus ujian, data ujian dan persiapan lingkungan ujian. Pada tahap perencanaan pengujian, akan dimulai perancangan metode pengujian yang paling sesuai dan perencanaan upaya pengujian mulai dari penentuan waktu pengujian hingga sistem yang akan diuji. Rencana pengujian adalah dokumen pertama yang harus disiapkan, yang menguraikan ruang lingkup, tujuan, fitur yang akan diuji, fitur yang tidak akan diuji, jenis pengujian yang akan dilakukan, peran dan tanggung jawab tim pengujian, kriteria dan asumsi masuk dan keluar [9]. Pada penelitian ini dilakukan uji rencana dengan menggunakan metode STLC sesuai dengan hasil tinjauan pustaka. Sistem yang akan diujicobakan sudah ditentukan di awal penelitian. Pengujian akan dilakukan pada Sistem Manajemen Pembelajaran Fakultas Ilmu Komputer Universitas Subang.

\section{Test Case Development}

Tahap ini akan memulai merancang skenario pengujian yang akan dilakukan untuk menguji fungsi sistem sesuai RTM dan rencana yang telah dibuat pada tahap perencanaan pengujian. Secara bersamaan, tim penguji mulai mempersiapkan kasus uji dan data uji. Kasus uji adalah dokumen, yang menguraikan langkah-langkah yang diperlukan untuk menguji fungsionalitas apa pun dengan hasil yang diharapkan dan aktual. Jika hasil sebenarnya tidak sesuai dengan hasil yang diharapkan, bug dibuka. Untuk setiap persyaratan, kasus uji positif dan negatif disiapkan, yang dikonfirmasi oleh matriks ketertelusuran persyaratan (RTM). RTM adalah dokumen yang memetakan persyaratan dengan kasus uji untuk memastikan pengujian $100 \%$ dilakukan. Semua kumpulan data pengujian yang valid dan tidak valid harus disiapkan untuk setiap kasus pengujian dan dokumen data pengujian harus disiapkan. Data uji juga dihasilkan berdasarkan beberapa algoritma dan alat
[10]. Penyusunan kasus uji [11] memiliki berbagai tahapan yang dimulai dengan pembuatan kasus uji [12], pemilihan kasus uji [13], evaluasi, dan prioritas kasus uji [14] [15]. Ada berbagai algoritma yang digunakan untuk menghasilkan dan mengoptimalkan kasus uji [16] [17] [18].

Swain et.al mengusulkan teknik untuk menghasilkan kasus uji menggunakan diagram urutan yang tepat serta menentukan batas di seluruh artefak yang ditentukan. Pada saat yang sama, teknik pembuatan kasus uji berguna untuk mendeteksi sinkronisasi dan ketergantungan kasus penggunaan dan pesan, interaksi objek, dan kesalahan operasi [19]. Langkah yang dilakukan pada tahap ini adalah membuat tabel deskripsi awal yang diperlukan. Tabel seperti yang terlihat pada Tabel 4 . berisi test $i d$ dan deskripsi test sebagai referensi yang nantinya akan dirinci kembali dalam bentuk skenario.

\section{TABEL IV. DESKRIPSI PENGUJIAN}

\begin{tabular}{ll} 
Test ID & \multicolumn{1}{c}{ Deskripsi Test } \\
\hline TC01 & $\begin{array}{l}\text { Login menggunakan kombinasi } \text { username dan } \\
\text { password yang salah. }\end{array}$ \\
\hline TC02 & Login menggunakan username yang tidak terdaftar. \\
\hline TC03 & $\begin{array}{l}\text { Login menggunakan password dengan menggunakan } \\
\text { spasi. }\end{array}$ \\
\hline TC04 & Input data melebihi kapasitas. \\
\hline TC05 & $\begin{array}{l}\text { Input data tidak pada tempatnya dengan } \\
\text { menggunakan special character. }\end{array}$ \\
\hline TC06 & Input blank pada filed. \\
\hline TC07 & View function berdasarkan hak akses. \\
\hline TC08 & View data inputan. \\
\hline TC09 & View Informasi berdasarkan hak akses. \\
\hline TC10 & Input Code html. \\
\hline TC11 & $\begin{array}{l}\text { Edit data tidak pada tempatnya dengan menggunakan } \\
\text { special character. }\end{array}$ \\
\hline TC12 & Edit dengan menggunakan data blank pada field. \\
\hline TC13 & Cek fitur lupa password. \\
\hline TC14 & Delete data master. \\
\hline TC15 & Mengganti Password lama dengan data baru. \\
\hline
\end{tabular}

\section{Environment Setup}

Tahap ini akan melihat bagaimana arsitektur yang dibutuhkan, lingkungan dan daftar spesifikasi perangkat keras dan lunak yang dibutuhkan untuk melakukan pengujian. Persiapan lingkungan pengujian adalah salah satu fase terpenting yang biasanya 
disiapkan oleh lingkungan penanganan tim terpisah. Setelah menyelesaikan bagian pengkodean, kode tersebut diperiksa oleh alat manajemen konfigurasi dan kemudian pembuatan pengujian disiapkan di mana penguji harus memulai pelaksanaan pengujian [8].

\section{Test Execution}

Pada tahap ini proses pengujian dilakukan berdasarkan skenario pengujian. dan jadwal pengujian yang telah dibuat. Pada tahap ini juga dibuat hasil yang diharapkan dari sistem yang diuji dan hasil dari proses pengujian itu sendiri. Dalam fase ini penguji menjalankan perangkat lunak sesuai dengan kasus pengujian. Jika hasil aktual dan yang diharapkan tidak cocok, penguji membuka bug dan menetapkan hal yang sama kepada pengembang. Logging dan pelacakan bug [12] mengikuti siklus hidup bug lengkap. Banyak pekerjaan yang telah dilakukan di masa lalu yang berfokus pada langkah-langkah utama yang harus dilakukan untuk melaporkan kesalahan yang valid. Laporan rutin dapat didiskusikan setiap minggu / setiap hari seiring kemajuan proyek dalam pelaksanaan proyek, penerimaan dan persetujuan dipantau untuk menganalisis proyek percontohan.

\section{Closure}

Pada tahap ini akan membahas hasil dari pengujian siklus dan menganalisis cara memperbaiki strategi pengujian yang digunakan, memperbaiki masalah proses pada siklus pengujian, dan mencari metode alternatif yang dapat digunakan dalam penelitian selanjutnya. Penutupan Uji adalah fase kritis yang mencakup semua laporan pengujian yang memastikan bahwa semua sistem, integrasi, pengujian penerimaan pengguna lolos, dan keputusan diambil apakah semua persyaratan telah diuji dan tidak ada critical bug yang menunggu untuk diperbaiki atau diverifikasi. Peninjauan semua artefak uji dilakukan oleh Manajer. Setelah semua artefak ditinjau dan disetujui, rilis perangkat lunak selesai. Analisis akar penyebab lebih lanjut sedang dilakukan untuk bertukar pikiran tentang apa yang berjalan dengan baik, apa yang tidak berhasil, dan area perbaikan. Ada berbagai alat dan metode analisis akar penyebab yang tersedia di mana banyak penelitian telah dilakukan di masa lalu.

Fase-fase tersebut digambarkan dalam tabel demografi pada Tabel 5. dibawah ini. Partisipan dalam pembuatan dokumen software testing dibagi kedalam tiga peran yaitu Test Manager, Test Analyst, dan Tester. Test Manager memiliki tanggung jawab memastikan kualitas seluruh pengujian yang terjadi pada semua fase dan menentukan standar pengujian. Sementara Test Analyst memiliki tanggung jawab dalam proses penguji termasuk merancang kasus uji dan mengembangkan proses pengujian. Tester bertanggung jawab dalam membuat dokumentasi yang sesuai dengan kasus pengujian, lingkup pengujian dan kebutuhan tes. Ketiga peran tersebut dijalankan oleh peneliti dan pihak Universitas Subang.

TABEL V. DEMOGRAFI PENELITIAN

\begin{tabular}{|c|l|l|l|l|}
\hline $\begin{array}{c}\text { N } \\
\text { O }\end{array}$ & FASE & $\begin{array}{l}\text { PARTI- } \\
\text { SIPAN }\end{array}$ & $\begin{array}{c}\text { DURASI } \\
\text { PENELITI } \\
\text { AN }\end{array}$ & $\begin{array}{l}\text { INSTRUMEN } \\
\text { PENELITIAN }\end{array}$ \\
\hline 1 & $\begin{array}{l}\text { Require } \\
\text { ment } \\
\text { Analysis }\end{array}$ & $\begin{array}{l}\text { Test } \\
\text { Analyst }\end{array}$ & 1 minggu & $\begin{array}{l}\text { Requirement } \\
\text { Traceability } \\
\text { Matrix }\end{array}$ \\
\hline 2 & $\begin{array}{l}\text { Test } \\
\text { Planning }\end{array}$ & $\begin{array}{l}\text { Test } \\
\text { Analyst }\end{array}$ & 1 minggu & $\begin{array}{l}\text { Rencana Proses } \\
\text { Uji }\end{array}$ \\
\hline 3 & $\begin{array}{l}\text { Test } \\
\text { Case } \\
\text { Develop } \\
\text { ment }\end{array}$ & $\begin{array}{l}\text { Test } \\
\text { Manager }\end{array}$ & 1 minggu & $\begin{array}{l}\text { Test case } \text { dan } \\
\text { Skenario } \\
\text { Testing }\end{array}$ \\
\hline 4 & $\begin{array}{l}\text { Environ } \\
\text { ment } \\
\text { Setup }\end{array}$ & $\begin{array}{l}\text { Test } \\
\text { Manager }\end{array}$ & 1 minggu & $\begin{array}{l}\text { Daftar } \\
\text { spesifikasi } \\
\text { Hardware dan } \\
\text { Software }\end{array}$ \\
\hline 5 & $\begin{array}{l}\text { Test } \\
\text { Executio } \\
n\end{array}$ & Tester & 3 minggu & $\begin{array}{l}\text { Expectation } \\
\text { outcome dan } \\
\text { Test Execution }\end{array}$ \\
\hline 6 & $\begin{array}{l}\text { Closure } \\
\text { Tester }\end{array}$ & 1 minggu & $\begin{array}{l}\text { Dokumen } \\
\text { Software } \\
\text { Testing. }\end{array}$ \\
\hline
\end{tabular}

\section{HASIL DAN PEMBAHASAN}

Pengujian dilakukan berdasarkan test scenario yang telah dibuat pada Tabel 3. Dengan test case id TC01 terlihat test execution pada Tabel 6. dengan aksi Login menggunakan kombinasi username atau password yang sama pada business requirement $\mathrm{B} 01$ yaitu User Access. Pada pengujian sistem TC01 ekpektasi outcome adalah username/password salah dan actual outcome seperti yang terlihat pada Gambar 4. yaitu invalid Login please try again.

TABEL VI. TEST EXECUTION TABEL CASE 1

\begin{tabular}{|c|c|c|c|c|}
\hline \multicolumn{5}{|c|}{ Test Case 1} \\
\hline No & Action & Input & $\begin{array}{l}\text { Expected } \\
\text { Outcome }\end{array}$ & Result \\
\hline \multirow[t]{3}{*}{1} & \multirow{3}{*}{$\begin{array}{l}\text { Login } \\
\text { menggunakan } \\
\text { kombinasi } \\
\text { dan password } \\
\text { yang salah } \\
\text { atau } \\
\text { sebaliknya }\end{array}$} & \multirow{3}{*}{$\begin{array}{l}\text { User: } \\
\text { Tazkia } \\
\text { Pass: } \\
\text { testing }\end{array}$} & $\begin{array}{l}\text { Usernamel } \\
\text { Password } \\
\text { salah }\end{array}$ & \multirow[t]{3}{*}{ Pass } \\
\hline & & & $\begin{array}{l}\text { Actual } \\
\text { Outcome }\end{array}$ & \\
\hline & & & $\begin{array}{l}\text { Invalid } \\
\text { Login } \\
\text { Please Try } \\
\text { Again }\end{array}$ & \\
\hline
\end{tabular}




\begin{tabular}{|c|c|c|c|c|}
\hline \multicolumn{5}{|c|}{ Test Case 1} \\
\hline No & Action & Input & $\begin{array}{l}\text { Expected } \\
\text { Outcome }\end{array}$ & Result \\
\hline \multirow[t]{4}{*}{2} & & \multirow{4}{*}{$\begin{array}{l}\text { User: } \\
\text { Denada } \\
\text { Pass: } 1234\end{array}$} & $\begin{array}{l}\text { Expected } \\
\text { Outcome }\end{array}$ & \multirow[t]{4}{*}{ Pass } \\
\hline & & & $\begin{array}{l}\text { Usenamel } \\
\text { Password } \\
\text { Salah }\end{array}$ & \\
\hline & & & $\begin{array}{l}\text { Actual } \\
\text { Outcome }\end{array}$ & \\
\hline & & & \begin{tabular}{|l|} 
Invalid \\
Login \\
Please Try \\
Again \\
\end{tabular} & \\
\hline
\end{tabular}

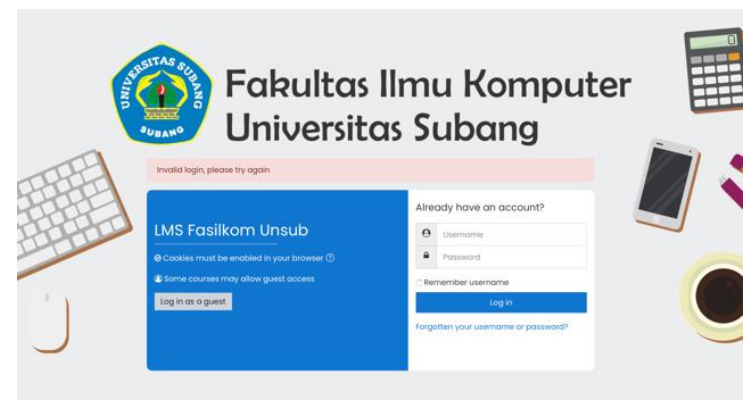

Gambar 4. Actual Outcome TC01

Pengujian selanjutnya dilakukan test case id TC02 terlihat test execution pada Tabel 7. dengan aksi menggunakan username yang tidak terdaftar pada LMS Fakultas Ilmu Komputer, Universitas Subang. Pengujian dilakukan pada business requirement B01 yaitu User Access. Pada pengujian sistem TC02 ekpektasi outcome adalah username tidak terdaftar dan actual outcome seperti yang terlihat pada Gambar 5 . yaitu invalid Login please try again.

TABEL VII. TEST EXECUTION TABEL CASE 2

\begin{tabular}{|c|c|c|c|c|}
\hline \multicolumn{5}{|c|}{ Test Case 2} \\
\hline No & Action & Input & $\begin{array}{l}\text { Expected } \\
\text { Outcome }\end{array}$ & Result \\
\hline \multirow[t]{3}{*}{1} & \multirow{3}{*}{$\begin{array}{l}\text { Login } \\
\text { menggunakan } \\
\text { username } \\
\text { yang tidak } \\
\text { terdaftar }\end{array}$} & \multirow{3}{*}{$\begin{array}{l}\text { User: } \\
\text { Fikri } \\
\text { Pass: } \\
1234\end{array}$} & $\begin{array}{l}\text { Username } \\
\text { tidak } \\
\text { terdaftar }\end{array}$ & \multirow[t]{3}{*}{ Pass } \\
\hline & & & $\begin{array}{l}\text { Actual } \\
\text { Outcome }\end{array}$ & \\
\hline & & & $\begin{array}{l}\text { Invalid } \\
\text { Login } \\
\text { Please Try } \\
\text { Again }\end{array}$ & \\
\hline
\end{tabular}

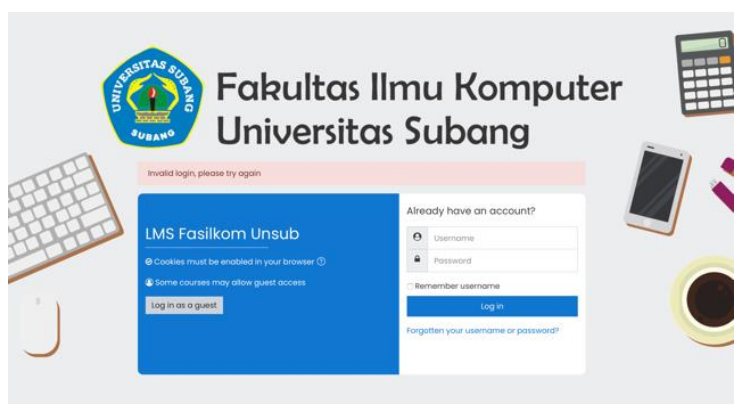

Gambar 5. Actual Outcome TC02

Pengujian TC03 dilakukan terlihat test execution pada Tabel 8. dengan aksi Login menggunakan password dengan menggunakan spasi pada LMS Fakultas Ilmu Komputer, Universitas Subang. Pengujian dilakukan pada business requirement $\mathrm{B} 01$ yaitu User Access. Pada pengujian sistem TC03 ekpektasi outcome adalah username/password salah dan actual outcome seperti yang terlihat pada Gambar 6. yaitu invalid Login please try again.

TABEL VIII. TEST EXECUTION TABEL CASE 3

\begin{tabular}{|c|c|c|c|c|}
\hline \multicolumn{5}{|c|}{ Test Case 3} \\
\hline No & Action & Input & $\begin{array}{l}\text { Expected } \\
\text { Outcome }\end{array}$ & Result \\
\hline \multirow{3}{*}{1} & \multirow{3}{*}{$\begin{array}{l}\text { Login dengan } \\
\text { menggunakan } \\
\text { password } \\
\text { dengan } \\
\text { menggunakan } \\
\text { spasi }\end{array}$} & \multirow{3}{*}{$\begin{array}{l}\text { User; } \\
\text { Tazkia } \\
\text { Pass: } \\
1234\end{array}$} & $\begin{array}{l}\text { Usernamel } \\
\text { Password } \\
\text { salah }\end{array}$ & \multirow[t]{3}{*}{ Pass } \\
\hline & & & $\begin{array}{l}\text { Actual } \\
\text { Outcome }\end{array}$ & \\
\hline & & & $\begin{array}{l}\text { Invalid } \\
\text { Login } \\
\text { Please Try } \\
\text { Again }\end{array}$ & \\
\hline
\end{tabular}

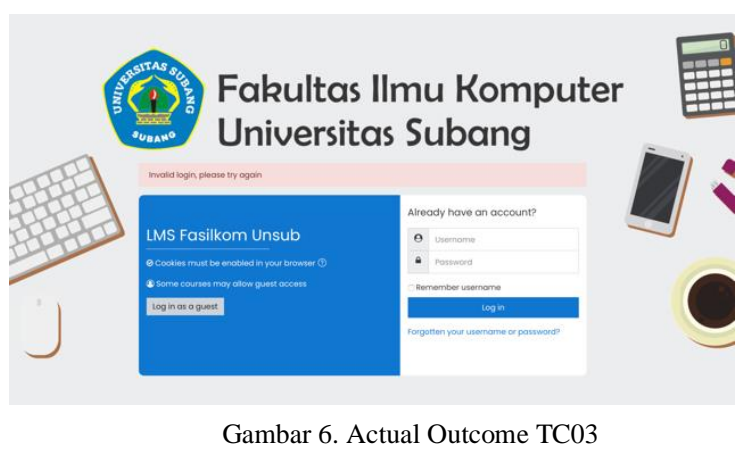

Pengujian selanjutnya dilakukan untuk TC04 yaitu dengan aksi input data melebihi kapasitas. Dalam pengujian ini peneliti mencoba menuliskan abjad tanpa henti. Expected income dari pengujian ini adalah tidak 
dapat input lagi begitupun dengan expected income tidak dapat input lagi. Dalam pengujian TC03 dilakukan pada business requirement yaitu General User Management.

TABEL IX. TEST EXECUTION TABEL CASE 4

\begin{tabular}{|c|c|c|c|c|}
\hline \multicolumn{5}{|c|}{ Test Case 4} \\
\hline No & Action & Input & $\begin{array}{l}\text { Expected } \\
\text { Outcome }\end{array}$ & Result \\
\hline \multirow{3}{*}{1} & \multirow{3}{*}{$\begin{array}{l}\text { Input data } \\
\text { melebihi } \\
\text { kapasitas }\end{array}$} & \multirow{3}{*}{$\begin{array}{l}\text { Menuliskan } \\
\text { seluruh abjad } \\
\text { tanpa henti }\end{array}$} & $\begin{array}{l}\text { Tidak } \\
\text { dapat input } \\
\text { lagi }\end{array}$ & \multirow[t]{3}{*}{ Pass } \\
\hline & & & $\begin{array}{l}\text { Actual } \\
\text { Outcome }\end{array}$ & \\
\hline & & & $\begin{array}{l}\text { Tidak } \\
\text { dapat input } \\
\text { lagi }\end{array}$ & \\
\hline
\end{tabular}

Pengujian pada Test Case kelima dengan test id TC05 dilakukan pada business requirement yang sama dengan TC04 yaitu General User Management. Aksi pada pengujian ini adalah input data tidak pada tempatnya menggunakan special character. Pada pengujian ini peneliti menuliskan email dengan "ccccccc" dengan expected outcome salah email dan actual outcome adalah 414Ieee82 seperti yang tertera pada Tabel 10.

TABEL X. TEST EXECUTION TABEL CASE 5

\begin{tabular}{|c|c|c|c|c|}
\hline \multicolumn{5}{|c|}{ Test Case 5} \\
\hline No & Action & Input & $\begin{array}{l}\text { Expected } \\
\text { Outcome }\end{array}$ & Result \\
\hline \multirow[b]{3}{*}{1} & \multirow{3}{*}{$\begin{array}{l}\text { Input data } \\
\text { tidak pada } \\
\text { tempatnya } \\
\text { dengan } \\
\text { menggunakan } \\
\text { special } \\
\text { karakter }\end{array}$} & \multirow{3}{*}{$\begin{array}{l}\text { Email: } \\
\text { eeeee }\end{array}$} & Salah email & \multirow[t]{3}{*}{ Pass } \\
\hline & & & Actual Outcome & \\
\hline & & & $x$ Q 414 leee 82 & \\
\hline
\end{tabular}

Sementara itu pengujian untuk Test Case 6 dengan id test TC06 menggunakan aksi input blank pada filed dengan tidak menginput apapun pada kolom. Expected outcome pada pengujian ini adalah harap diisi sementara actual outcome adalah missing given name seperti yang terlihat pada Tabel 11 . Pengujian ini dilakukan pada business requirement yang sama dengan TC04 dan TC05 yaitu General User Management.
TABEL XI. TEST EXECUTION TABEL CASE 6

\begin{tabular}{|c|c|c|c|c|}
\hline \multicolumn{5}{|c|}{ Test Case 6} \\
\hline No & Action & Input & $\begin{array}{l}\text { Expected } \\
\text { Outcome }\end{array}$ & Result \\
\hline \multirow{3}{*}{1} & \multirow{3}{*}{$\begin{array}{l}\text { Input blank } \\
\text { pada fileld }\end{array}$} & \multirow{3}{*}{$\begin{array}{l}\text { Tidak } \\
\text { input } \\
\text { apapun }\end{array}$} & Harap diisi & \multirow[t]{3}{*}{ Pass } \\
\hline & & & $\begin{array}{l}\text { Actual } \\
\text { Outcome }\end{array}$ & \\
\hline & & & - Mssing given nome & \\
\hline
\end{tabular}

Pengujian test case ketujuh dengan id test TC07 dilakukan pada beberapa business requirement yaitu Dashboard System, General User Management, Learner/ Student Management, Learning Content Management Capabilities, Classroom Management, Online Learning Portal, Learning Management Report, dan Plugin Management. Aksi pada pengujian ini terbagi dua yaitu hak akses Admin dan hak akses Mahasiswa dengan keduanya memiliki aksi view function berdasarkan hak akses. Seperti terlihat pada Tabel 12. bahwa expected outcome untuk kedua hak akses baik mahasiswa maupun admin adalah dapat menggunakan semua fungsi sementara untuk hak akses. Sementara actual outcome berbeda, untuk hak akses Admin dapat menggunakan semua fungsi sementara untuk mahasiswa tidak dapat menggunakan semua fungsi.

TABEL XII. TEST EXECUTION TABEL CASE 7

\begin{tabular}{|c|c|c|c|c|}
\hline \multicolumn{5}{|c|}{ Test Case 7} \\
\hline No & Action & Input & $\begin{array}{l}\text { Expected } \\
\text { Outcome }\end{array}$ & Result \\
\hline \multirow{3}{*}{1} & \multirow{3}{*}{$\begin{array}{l}\text { View } \\
\text { function } \\
\text { berdasarkan } \\
\text { hak akses }\end{array}$} & \multirow{3}{*}{$\begin{array}{l}\text { Hak akses: } \\
\text { Admin }\end{array}$} & $\begin{array}{l}\text { Data } \\
\text { menggunakan } \\
\text { semua fungsi }\end{array}$ & \multirow[t]{3}{*}{ Pass } \\
\hline & & & $\begin{array}{l}\text { Actual } \\
\text { Outcome }\end{array}$ & \\
\hline & & & $\begin{array}{l}\text { Dapat } \\
\text { menggunakan } \\
\text { semua fungsi }\end{array}$ & \\
\hline \multirow{4}{*}{2} & \multirow{4}{*}{$\begin{array}{l}\text { View } \\
\text { function } \\
\text { berdasarkan } \\
\text { hak akses }\end{array}$} & \multirow{4}{*}{$\begin{array}{l}\text { Hak akses: } \\
\text { Mahasiswa }\end{array}$} & $\begin{array}{l}\text { Expected } \\
\text { Outcome }\end{array}$ & \multirow{4}{*}{ Pass } \\
\hline & & & $\begin{array}{l}\text { Tidak dapat } \\
\text { menggunakan } \\
\text { semua fungsi }\end{array}$ & \\
\hline & & & $\begin{array}{l}\text { Actual } \\
\text { Outcome }\end{array}$ & \\
\hline & & & $\begin{array}{l}\text { Tidak dapat } \\
\text { menggunakan } \\
\text { semua fungsi }\end{array}$ & \\
\hline
\end{tabular}

Pengujian selanjutnya dilakukan pada test case 8 dengan id TC08 yang dilakukan pada business requirement General User Management. Aksi pada 
pengujian ini adalah view data inputan dengan input melihat data. Expected income pada pengujian ini seperti terlohat pada Tabel 13. Sementara actual income pada pengujian ini adalah dapat dilihat.

TABEL XIII. TEST EXECUTION TABEL CASE 8

\begin{tabular}{|c|c|c|c|c|}
\hline \multicolumn{5}{|c|}{ Test Case 8} \\
\hline No & Action & Input & $\begin{array}{l}\text { Expected } \\
\text { Outcome }\end{array}$ & Result \\
\hline \multirow{3}{*}{1} & \multirow{3}{*}{$\begin{array}{l}\text { View data } \\
\text { inputan }\end{array}$} & \multirow{3}{*}{$\begin{array}{l}\text { Melihat } \\
\text { Data }\end{array}$} & $\begin{array}{l}\text { Dapat } \\
\text { dilihat }\end{array}$ & \multirow[t]{3}{*}{ Pass } \\
\hline & & & $\begin{array}{l}\text { Actual } \\
\text { Outcome }\end{array}$ & \\
\hline & & & $\begin{array}{l}\text { Dapat } \\
\text { dilihat }\end{array}$ & \\
\hline
\end{tabular}

Pengujian test case kesembilan dengan id test TC09 dilakukan pada beberapa business requirement yaitu Dashboard System, General User Management, Learner/ Student Management, Learning Content Management Capabilities, Classroom Management, Online Learning Portal, Learning Management Report, dan Plugin Management. Aksi pada pengujian ini terbagi dua yaitu hak akses Admin dan hak akses Mahasiswa dengan keduanya memiliki aksi view informasi berdasarkan hak akses. Seperti terlihat pada Tabel 14. bahwa expected outcome untuk hak akses admin adalah dapat melihat seluruh informasi sementara untuk hak akses mahasiswa semester 3 adalah hanya dapat melihat informasi semester 3 . Actual outcome untuk kedua akses sama dengan expected outcome masing-masing akses tersebut.

TABEL XIV. TEST EXECUTION TABEL CASE 9

\begin{tabular}{|c|c|c|c|c|}
\hline \multicolumn{5}{|c|}{ Test Case 9} \\
\hline No & Action & Input & $\begin{array}{l}\text { Expected } \\
\text { Outcome }\end{array}$ & Result \\
\hline \multirow{3}{*}{1} & \multirow{3}{*}{$\begin{array}{l}\text { View } \\
\text { Informasi } \\
\text { berdasarkan } \\
\text { hak akses }\end{array}$} & \multirow{3}{*}{$\begin{array}{l}\text { Hak akses: } \\
\text { Admin }\end{array}$} & $\begin{array}{l}\text { Dapat } \\
\text { melihat } \\
\text { seluruh } \\
\text { informasi }\end{array}$ & \multirow[t]{3}{*}{ Pass } \\
\hline & & & $\begin{array}{l}\text { Actual } \\
\text { Outcome }\end{array}$ & \\
\hline & & & $\begin{array}{l}\text { Dapat } \\
\text { melihat } \\
\text { seluruh } \\
\text { informasi }\end{array}$ & \\
\hline \multirow{3}{*}{2} & \multirow{3}{*}{$\begin{array}{l}\text { View } \\
\text { informasi } \\
\text { berdasarkan } \\
\text { hak akses }\end{array}$} & \multirow{3}{*}{$\begin{array}{l}\text { Hak } \\
\text { Akses: } \\
\text { Mahasiswa } \\
\text { Semester } 3\end{array}$} & $\begin{array}{l}\text { Expected } \\
\text { Outcome }\end{array}$ & \multirow{3}{*}{ Pass } \\
\hline & & & $\begin{array}{l}\text { Hanya } \\
\text { dapat } \\
\text { melihat } \\
\text { informasi } \\
\text { semester 3 }\end{array}$ & \\
\hline & & & $\begin{array}{l}\text { Actual } \\
\text { Outcome }\end{array}$ & \\
\hline
\end{tabular}

\begin{tabular}{|l|c|l|l|l|}
\hline \multicolumn{2}{|l|}{ Test Case 9 } & Input & $\begin{array}{l}\text { Expected } \\
\text { Outcome }\end{array}$ & Result \\
\hline No & Action & & Hanya & \\
& & & dapat & \\
& & & melihat & \\
& & & informasi & \\
& & & semester 3 & \\
& & & \\
\hline
\end{tabular}

Pengujian selanjutnya dilakukan pada test case 11 dengan id TC11 yang dilakukan pada business requirement General User Management. Aksi pada pengujian ini adalah edit data tidak pada tempatnya dengan menggunakan special character. Pada pengjian ini peneliti memasukan angka 1234 pada kolom email. Expected income pada pengujian ini seperti terlihat pada Tabel 15 yaitu email salah. Sementara actual income pada pengujian 414 Ieee82.

TABEL XV. TEST EXECUTION TABEL CASE 11

\begin{tabular}{|c|c|c|c|c|}
\hline \multicolumn{5}{|c|}{ Test Case 11} \\
\hline No & Action & Input & $\begin{array}{l}\text { Expected } \\
\text { Outcome }\end{array}$ & Result \\
\hline \multirow[b]{3}{*}{1} & \multirow{3}{*}{$\begin{array}{l}\text { Edit data tidak } \\
\text { pada } \\
\text { tempatnya } \\
\text { dengan } \\
\text { menggunakan } \\
\text { special } \\
\text { character }\end{array}$} & \multirow[b]{3}{*}{$\begin{array}{l}\text { Email: } \\
1234\end{array}$} & Email salah & \multirow[t]{3}{*}{ Pass } \\
\hline & & & Actual Outcome & \\
\hline & & & $\times$ O 414 leee 82 & \\
\hline
\end{tabular}

Pengujian selanjutnya dilakukan pada test case 12 dengan nomor test id TC14 dengan aksi edit dengan menggunakan data blank pada field. Peneliti tidak mengisikan apapun pada kolom. Terlihat pada Tabel 16. bahwa expected outcome adalah harap diisi sementara actual outcome adalah missing given name. Pengujian TC12 dilakukan pada business requirement General User Management.

TABEL XVI. TEST EXECUTION TABEL CASE 12

\begin{tabular}{|c|c|c|c|c|}
\hline \multicolumn{5}{|c|}{ Test Case 12} \\
\hline No & Action & Input & $\begin{array}{l}\text { Expected } \\
\text { Outcome }\end{array}$ & Result \\
\hline \multirow[b]{2}{*}{1} & \multirow[b]{2}{*}{$\begin{array}{l}\text { Edit dengan } \\
\text { menggunakan } \\
\text { data blank } \\
\text { pada field }\end{array}$} & & Harap diisi & \multirow[t]{2}{*}{ Pass } \\
\hline & & & $\begin{array}{l}\text { Actual } \\
\text { Outcome }\end{array}$ & \\
\hline
\end{tabular}

Pengujian test case 13 dengan test id $\mathrm{TC} 13$ dilakukan pada business requirement BR10 yaitu Administrative Function. Pengujian ini untuk mengecek fitur lupa password dengan pengujian klik forgotten username or password username. Expected 
outcome pada pengujian ini adalah new password seperti terlihat pada Tabel 17.

TABEL XVII. TEST EXECUTION TABEL CASE 13

\begin{tabular}{|c|c|c|c|c|}
\hline \multicolumn{5}{|c|}{ Test Case 13} \\
\hline No & Action & Input & $\begin{array}{l}\text { Expected } \\
\text { Outcome }\end{array}$ & Result \\
\hline \multirow[b]{3}{*}{1} & \multirow[b]{3}{*}{$\begin{array}{l}\text { Cek fitur } \\
\text { lupa } \\
\text { password }\end{array}$} & \multirow{3}{*}{$\begin{array}{l}\text { Klik } \\
\text { forgotten } \\
\text { username } \\
\text { or } \\
\text { password } \\
\text { by } \\
\text { username }\end{array}$} & New password & \multirow[t]{3}{*}{ Pass } \\
\hline & & & Actual Outcome & \\
\hline & & & 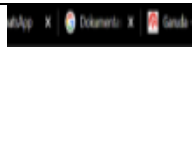 & \\
\hline
\end{tabular}

Pengujian test case 14 dengan test id TC14 dilakukan pada business requirement BR10 yaitu Administrative Function. Pengujian ini dilakukan untuk delete data master dengan input delete seperti terlihat pada Tabel 18. Expected outcome pada pengujian ini adalah terhapus dan actual outcome adalah data terhapus.

TABEL XVIII. TEST EXECUTION TABEL CASE 14

\begin{tabular}{|c|c|c|c|c|}
\hline \multicolumn{5}{|c|}{ Test Case 14} \\
\hline No & Action & Input & $\begin{array}{l}\text { Expected } \\
\text { Outcome }\end{array}$ & Result \\
\hline \multirow{3}{*}{1} & \multirow{3}{*}{$\begin{array}{l}\text { Delete data } \\
\text { master }\end{array}$} & \multirow{3}{*}{ Delete } & Terhapus & \multirow[t]{3}{*}{ Pass } \\
\hline & & & $\begin{array}{l}\text { Actual } \\
\text { Outcome }\end{array}$ & \\
\hline & & & $\begin{array}{l}\text { Data } \\
\text { terhapus }\end{array}$ & \\
\hline
\end{tabular}

Pengujian test case 15 dengan test id TC15 dilakukan pada business requirement BR10 yaitu Administrative Function. Pengujian ini untuk mengganti password lama dengan data baru dengan input ganti password. Terlihat pada Tabel 19. untuk expexted outcome adalah password berhasil diganti dan actual outcome adalah password berhasil diganti.

TABEL XIX. TEST EXECUTION TABEL CASE 15

\begin{tabular}{|c|c|c|c|c|}
\hline \multicolumn{5}{|c|}{ Test Case 15} \\
\hline No & Action & Input & $\begin{array}{c}\text { Expected } \\
\text { Outcome }\end{array}$ & Result \\
\hline \multirow{3}{*}{1} & \multirow{3}{*}{$\begin{array}{l}\text { Mengganti } \\
\text { password } \\
\text { lama dengan } \\
\text { data baru }\end{array}$} & \multirow{3}{*}{$\begin{array}{l}\text { Ganti } \\
\text { Password }\end{array}$} & $\begin{array}{l}\text { Password } \\
\text { berhasil } \\
\text { diganti }\end{array}$ & \multirow[t]{3}{*}{ Pass } \\
\hline & & & $\begin{array}{l}\text { Actual } \\
\text { Outcome }\end{array}$ & \\
\hline & & & $\begin{array}{l}\text { Password } \\
\text { berhasil } \\
\text { diganti }\end{array}$ & \\
\hline
\end{tabular}

Setelah melakukan pengujian sistem TC1 hingga TC15 pada 10 business requirement pada 4 aspek yaitu security, data integrity, functional, dan recovery maka didapatkan hasil sebagai berikut:

TABEL XX. HASIL PENGUJIAN DALAM RTM

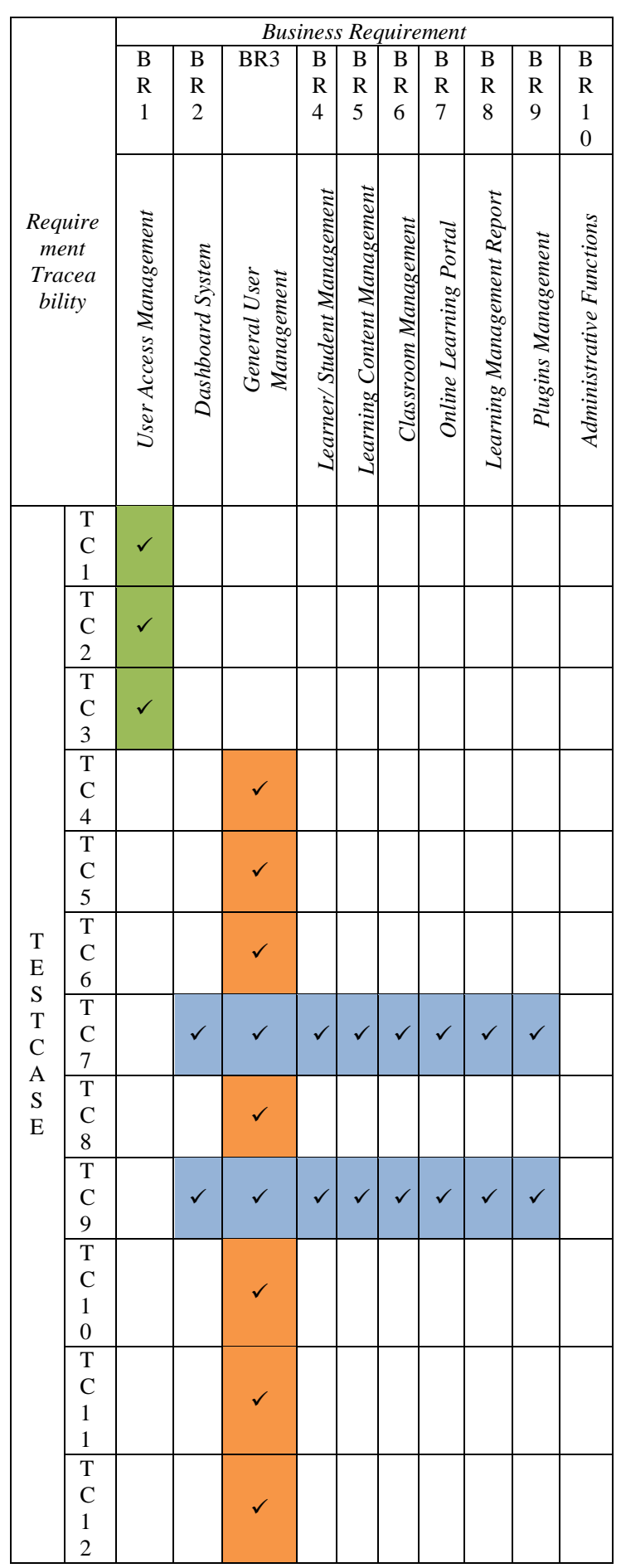




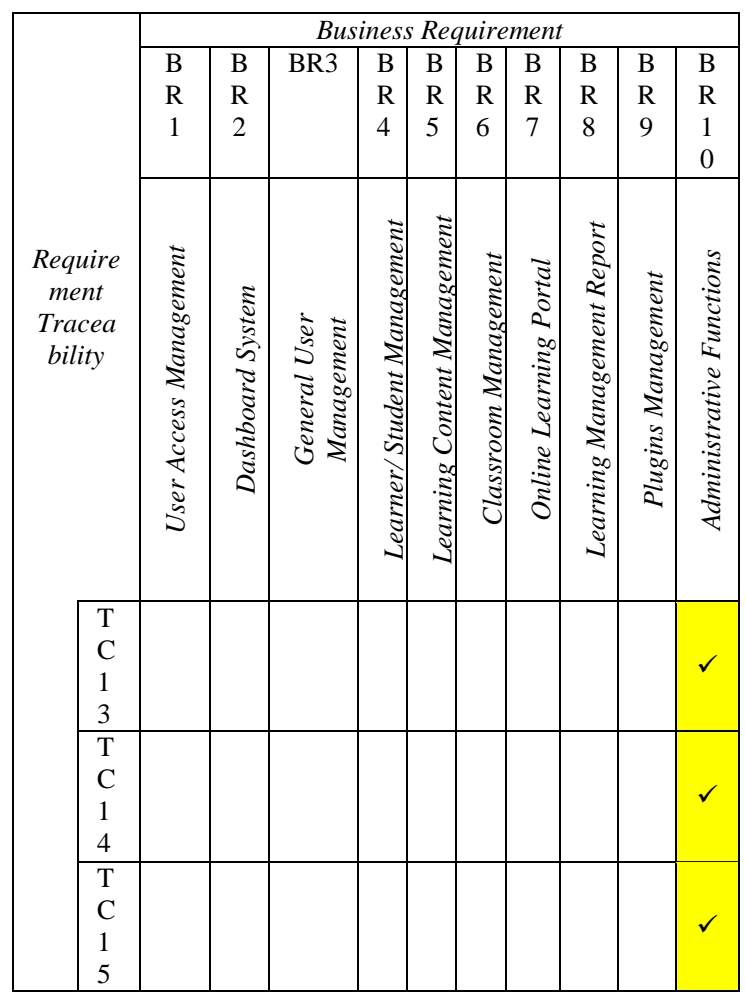

Kode :

SSTD - LMS Tabel RTM Security
SSTD - LMS Tabel RTM Data Integrity
SSTD - LMS Tabel RTM Functional
SSTD - LMS Tabel RTM Recovery

Berdasarkan hasil uji Tabel 18, didapatkan Hasil requirement traceability pada aspek security menghasilkan $100 \%$ pass dari 8 kali tahap pengujian dengan 3 case yang berbeda. Pada aspek data integrity juga menghasilkan $100 \%$ pass dari 20 kali tahap pengujian dengan 2 case yang berbeda. Sementara aspek fungsional hanya mengasilkan $82 \%$ Pass sebanyak 15 kali dari 18 tahap pengujian dengan 7 case yang berbeda. Aspek lainnya yaitu aspek recovery menghasilkan $100 \%$ pass dari tahap pengujian dengan 2 case yang berbeda.

\section{KESIMPULAN DAN SARAN}

Penerapan standar pengujian dengan metode STLC pada proses uji dengan proses pengerjaan yang urut dan tertata didapatkan hasil proses pengujian yang baik. Hampir keseluruhan sistem mempunyai hasil lulus $100 \%$, dengan dipetakan menggunakan matrix RTM. Pada pembuatan case/skenario test dirancang berdasarkan requirement dan ditambahi beberapa case acak yang berguna untuk mencari kesalahan pada sistem.

Dengan menggunakan Metode pengujian pada software pada studi kasus Learning Management System, Fakultas Ilmu Komputer, Universitas Subang ini menggunakan metodologi STLC (Software Testing Life Cycle) hasilnya kesimpulan yang di dapatkan setelah melakukan proses pengujian terhadap sistem Learning Management System Fakultas Ilmu Komputer adalah standar yang dimiliki sudah cukup baik. Functional sistem yang ada sudah berjalan sesuai dengan document requirement yang telah dibuat. Serta system yang dibagi berdasarkan hak akses pun, sudah cukup baik dalam proses pelaksanaannya.

Pengerjaan dokumentasi selanjutnya diharapkan scenario test dapat dibuat lebih spesifik untuk seitan sistem atau fungsi yang terdapat di LMS Fakultas Ilmu Komputer, Universitas Subang, baik untuk Mahasiswa maupun pihak Akademik. Hal tersebut termasuk dalam pengembangan skenario yang disesuaikam dengan kebutuhan sistem. Jika LMS berkembang maka semakin besar scope pengujian yang harus dilakukan serta dokumentasi yang harus dibuat. Lalu disarankan pula untuk di lakukan pengujian dengan metode lain untuk memastikan keamanan di Learning Management System, Fakultas Ilmu Komputer, Universitas Subang. Semakin berkembangnya system pula semakin rentan terhadapat kemanan. Jadi Learning Management System, Fakultas Ilmu Komputer, Universitas Subang agar selalu melakukan update dalam hal keamanan sistem.

Fakultas Ilmu Komputer maupun Universitas Subang secara keseluruhan dan peneliti selanjutnya dapat melakujan pengujian menggunakan standar pengujian lain yang terdapat pada Tabel 1. Penggunaan standar lain dapat memperlihatkan hasil dokumen software testing yang berbeda sehingga akan menjaga dan meningkatkan kualitas LMS. Selain itu juga dapat melakukan pembuatan document testing yang lebih luas yang mencakup dokumen kebutuhan, dokumen arsitektur dan desain, dokumen teknis, dokumen end user, dan dokumen pemasaran. Pengujian juga dapat diperluas dengan melibatkan user dalam hal ini adalah dosen dan mahasiswa.

\section{REFERENSI}

[1] The Institute of Electrical and Electronics Engineers, IEEE Standard for Software and System Test Documentation. 3 Park Avenue. New York, 2019.

[2] Systeme Evolutif Limited, IEEE Test Plan Template, 2019.

[3] P., Adi, "Jurnal Software Testing Aplikasi Website PT. Gramedia Menggunakan Metode Blackbox Pada PT WGS Bandung," E-Journal Universitas Dianapura, 2013. 
[4] R. Maulana, et al, "Software Testing pada Aplikasi Website PT Semen Tonasa menggunakan Metode Assessment Vulnerability," Jurnal INSYPRO (Information System and Processing), 2017.

[5] M. A. H. Anwar, Y. Kurniawan, "Dokumentasi Software Testing Berstandar Ieee 829-2008 Untuk Sistem Informasi Terintegrasi Universitas. Kurawal", Jurnal Teknologi, Informasi dan Industri, 2(2), 118-125, 2019.

[6] B. R. Marbun. Perancangan Proses Pengujian Regresi Terotomatisasi Menggunkan Sofware Testing Standard ISO/IEC 29119 Pada Proses Pengembangan Perangkat Lunak: Studi Kaus PT XYZ.Universitas Indonesia. 2016

[7] Dwanoko, Y. S. (2016). Implementasi Software Development Life Cycle (SDLC) Dalam Penerapan Pembangunan Aplikasi Perangkat Lunak. Jurnal Teknologi Informasi: Teori, Konsep, dan Implementasi, 7(2), 143003

[8] I. Hooda et al., "Software Test Process, Testing Type, and Techniques." International Journal of Computer Application, Vol.111-No.13, 2015.

[9] Vasanthapriyan, S., Tian, J., \& Xiang, J. (2017, November). An ontology-based knowledge framework for software testing. In International Symposium on Knowledge and Systems Sciences (pp. 212-226). Springer, Singapore.
[10] Park, J. K. (2018). A Development Method of Safety Critical Software for Nuclear Facilities. In Proceedings of the Korea Information Processing Society Conference (pp. 229-231). Korea Information Processing Society.

[11] Dewi, E. K., \& Azhari, S. N. (2012). Analisis Keamanan Sistem Perangkat Lunak. Seminar Nasional Aplikasi Teknologi Informasi (SNATI).

[12] B. Harsh, "Black Box Testing based on Requirement Analysis and Design Specifications," International Journal of Computer Applications (0975 - 8887) .18,18, 2014.

[13] W. Kumar, "Test Case Generation Based on Use case and Sequence Diagram." International Journal of Software Engineering (IJSE), 2010.

[14] B. Alkhales, "Effective Bug Tracking Systems.Theories and Implementation," IOSR Journal of Computer Engineering ISSN:2278-0661 Volume 4,Issue 6 pp 31-36, 2012.

[15] B.Beizer, "Software Testing Techniques" Van Nostrand Reinhold, 1990.ISBN.0-442-20672- 0, 2006.

[16] G.McGraw, "Software Security Testing," IEEE Security and Privacy 2.2," 2004. 